\title{
Potential Routes and Innovative Technologies for Valorisation of Cassava Peels
}

\author{
Bemgba B. Nyakuma* \\ Department of Chemistry, Faculty of Sciences, Benue State University, \\ P. M. B 102119 Makurdi, Benue State, Nigeria. \\ ${ }^{*}$ Correspondence email: $\underline{\text { bnbevan2@live.utm.my }}$
}

\begin{abstract}
The large-scale processing of Cassava (Manihot esculenta Crantz.) generates significant quantities of solid wastes annually. Cassava peels (CP) account for $5 \mathrm{wt}$.\% $30 \mathrm{wt} . \%$ of wastes from the processing of cassava tubers. The poor disposal and management of $\mathrm{CP}$ pose risks to human health, safety and the environment. Therefore, there is an urgent need to identify and examine low cost, socially acceptable and environmentally friendly strategies to mitigate the immediate and long terms disposal and management challenges. Lack of such measures results in the accumulation of $\mathrm{CP}$ wastes, which are currently buried, combusted, or dumped in open fields. Therefore, this paper reviewed the potential routes for the biochemical, thermochemical, and plasma valorisation of $\mathrm{CP}$. The literature reviewed revealed that biochemical technologies such as anaerobic digestion (AD) and fermentation are the most widely utilised approaches currently adopted for $\mathrm{CP}$ valorisation. AD produces biogas (methane 50-72 vol. \% and carbon dioxide 25-45 vol. \%), whereas fermentation yields bioethanol. However, the numerous challenges such as substrate-induced inhibition associated with the biochemical processes hamper microbial degradation, methane formation, and process efficiency. Furthermore, the processes generate secondary wastes or digestate/sludge, which requires additional processing before disposal. Therefore, innovative thermal, thermochemical, and plasma technologies were proposed to valorise $\mathrm{CP}$ into syngas, biofuels, bioenergy, biochemicals, and fertilizers, among others. However, the waste products of fermentation cannot be effectively utilised as bio-fertilizers, whereas bioethanol causes corrosion in engines. Overall, the biochemical, thermal, thermochemical and plasma technologies can effectively valorise $\mathrm{CP}$ for effective net energy generation.
\end{abstract}

Keywords: Cassava peels, valorisation, thermal, thermo-chemical, biochemical, biogas. 


\section{Introduction}

In today's global civilization, the pressure on fossil fuels has resulted in the attenuation of global reserves [1]. Likewise, the burning of fossil fuels for energy emits significant quantities of greenhouse gases (GHG) that jeopardize humans and the environment $[2,3]$. Hence, there is an urgent need for long-term strategies for the exploitation of renewable energy technologies (RETs) and clean fuels that could complement or substitute fossil fuels in the short or long term $[4,5]$. One of the most suitable approaches is the energy from biomass [6, 7]. Various studies have demonstrated the potential of RETs as innovative and prospective approaches for mitigating greenhouse gases, which could possibly address global warming and climate change $[8,9]$. It is envisaged that the adoption of RETs could satisfy humanity's growing demand for energy and fortify local economies [10, 11].

Biogas is a colourless, combustible, and low-priced RET generated through various biochemical technologies such as anaerobic digestion (AD) of natural waste materials $[12,13]$. Hence, the process is widely considered a practical solution that could satisfy the energy needs of rural populations [14, 15]. It is also clean, smokeless, and more suitable fuel to utilize than other solids fuel [16]. Typically, biogas (also known as digester gas) refers to the yield of methane from the fermentation of natural matter. Examples of such natural matter include wastewater, manure, municipal solid waste (MSW), sludge and other biodegradable feedstocks suitable for anaerobic digestion. Biogas produced under anaerobic conditions is a resource-efficient approach for managing a huge quantity of solid waste generated. Hence, it is a sustainable method of energy generation. The constituents of biogas include methane (50 - $72 \mathrm{vol}$. $\%$ ), carbon dioxide (25 - 45 vol. \%), nitrogen (>2 vol. \%), hydrogen sulphide (> 1 vol. \%), oxygen (>2 vol. \%) and water (2 - 7 vol. \%) $[17,18]$.

Similarly, biogas can be generated from raw materials such as agricultural wastes, which can vary from animal wastes to various crop residues. For example, 
cassava peels $(\mathrm{CP})$, obtained from cassava tubers, can be used as feedstock to produce biogas through anaerobic processes. The cassava (Manihot esculenta) tuber is cultivated mainly in the tropics and subtropical countries of the world. It is an essential source of food, which could stimulate socio-economic growth, sustainable development and offer food security [19]. The utilization of $\mathrm{CP}$ also offers immense prospects for the manufacture of bioenergy, particularly biogas, due to its chemical makeup. CP contains a high concentration of cyanogenic glucosides, which is inappropriate for animal feed [20]. Over the years, the haphazard dumping of CP has generated grave environmental concerns due to chemical contamination as well as potential risks to human health and safety [21, 22]. The breakdown of $\mathrm{CP}$ wastes produces poisonous leachates that pollute the environment. Furthermore, when the gases from the leachates are inhaled by humans, it could result in infectious diseases that could take effect within a short time. Similarly, plant life and soil within the region of degradation could be severely affected by biological processes or chemical reactions [23, 24].

For these reasons, it is imperative to explore alternatives to manage the growing stockpiles of solid CP waste generated from processing cassava, which could potentially guarantee a hazard-free environment. Hence, the utilization of solid CP wastes as either standalone raw material or combined feedstock to produce bioenergy, biofuels, and biomaterials has been extensively examined in the literature. Cuzin et al. [25] investigated the use of solid CP waste as feedstock to produce biogas. Similarly, the use of poultry manure combined with solid $\mathrm{CP}$ waste for biogas production has been reported in the literature [26, 27]. Others have examined the combined utilization of CP and cow dung blends for biogas production [28, 29]. In a later study, Okudoh and Trois [30] explored the use of CP and Zebra droppings, while Ukpai and Nnabuchi [28] scrutinized the use of CP and Cowpea for biogas production. Bayitse et al. [31] explored the use of $\mathrm{CP}$ with manure blends to produce biogas and bio-fertilizer by optimizing the ratio of carbon to nitrogen. There are other comprehensive research works on the 
valorisation of CP wastes into clean technologies, bioenergy, biofuels and biogas. The various approaches and technologies aim to effective and optimally recovery energy from $\mathrm{CP}$ as well as reduce the environmental burden of fossil-based fuels, energy and materials. Therefore, the primary focus of this review article is to abridge the conventional and more recent technologies utilised for energy, materials, and resources recovery from $\mathrm{CP}$ in literature.

\section{Cassava Peels (CP)}

$\mathrm{CP}$ is defined as the solid wastes generated from the processing of cassava (Manihot esculenta) tubers into essential products. It is also considered the significant portion of post-harvest losses obtained from the processing of cassava tubers for either industrial uses or domestic consumption. Typically, CP accounts for $8-15 \mathrm{wt} \%$ of the entire dry matter of the root [20]. Cassava tubers are rich in carbohydrates, proteins starch, and fats, which are typically used to produce staple foods [32]. It is a dependable source of energy, sweeteners and raw material for industry [33, 34]. When peeled mechanically, CP constitutes around 5\% to $10 \%$ of the solid waste [35], but when peeled manually is $20 \%-30 \%$ solid waste from cassava tubers [36, 37]. However, CP contains toxic cyanogenic glycosides [29]. The presence of toxic cyanogenic glycosides negatively affects biogas production, as such treatment is required to enhance the yield and onset of gas flammability [38]. CP consists of hemicellulose, cellulose, and lignin along with crude protein, organic matter and ash, as presented in Table 1 [20]. Chemical analysis of $\mathrm{CP}$ contains the following minerals; carbon $(\mathrm{C})$, nitrogen $(\mathrm{N})$, potassium $(\mathrm{K})$, phosphorus $(\mathrm{P})$, calcium $(\mathrm{Ca})$, sodium $(\mathrm{Na})$, zinc $(\mathrm{Zn})$, manganese $(\mathrm{Mn})$, copper $(\mathrm{Cu})$, and lead $(\mathrm{Pb})$, as shown in Table 1 [27].

Table 1: Chemical properties of CP [20]. 


\begin{tabular}{|c|c|c|c|}
\hline Analysis & Property & Symbol & Proportion \\
\hline \multirow{5}{*}{ Lignocelluloses } & Hemicellulose & $\mathrm{H}$ & $20-31$ wt. $\%$ \\
\hline & Cellulose & $\mathrm{C}$ & $16-42$ wt. $\%$ \\
\hline & Lignin & $\mathrm{L}$ & $6-8$ wt. $\% \%$ \\
\hline & Crude Protein & $\mathrm{CP}$ & $4.1-6.5$ wt. $\% \%$ \\
\hline & Organic matter & $\mathrm{OM}$ & 81.9-93.9 wt. \% \\
\hline \multirow{3}{*}{$\begin{array}{c}\text { Chemical Elemental } \\
\text { Composition }\end{array}$} & Carbon & $\mathrm{C}$ & 48.7 wt. $\%$ \\
\hline & Nitrogen & $\mathrm{N}$ & $1 \%$ wt. $\%$ \\
\hline & Carbon/Nitrogen ratio & $\mathrm{C} / \mathrm{N}$ & $48.7 \%$ wt. $\%$ \\
\hline \multirow{9}{*}{$\begin{array}{l}\text { Metal Element } \\
\text { Composition }\end{array}$} & Potassium & K & 1.1 wt. $\%$ \\
\hline & Phosphorus & $\mathrm{P}$ & $1.6 \mathrm{wt} . \%$ \\
\hline & Calcium & $\mathrm{Ca}$ & 0.9 wt. $\%$ \\
\hline & Sodium & $\mathrm{Na}$ & 0.15 wt. $\%$ \\
\hline & Zinc & $\mathrm{Zn}$ & $125 \mathrm{mg} / \mathrm{kg}$ \\
\hline & Manganese & $\mathrm{Mn}$ & $180 \mathrm{mg} / \mathrm{kg}$ \\
\hline & Copper & $\mathrm{Cu}$ & $15 \mathrm{mg} / \mathrm{kg}$ \\
\hline & Lead & $\mathrm{Pb}$ & $16.7 \mathrm{mg} / \mathrm{kg}$ \\
\hline & Nitrate & $\mathrm{NO}_{3}$ & 0.16 wt. $\%$ \\
\hline
\end{tabular}

Furthermore, Cassava has numerous merits when compared to other crops. It can be cultivated in every land, even in low soil fertility where most crops such as maize and other crops cannot thrive [39, 40]. It has a high yield of carbohydrates $(4.742$ $\mathrm{kg} / \mathrm{carb}$ ) per area of land besides sugarcane and sugar beet [30]. With an anticipated rise in cassava production globally, the generation of solid CP waste will rise continuously. Although drying solid CP waste can reduce toxic cyanogenic glycosides after utilization, large quantities are simply burned, buried or openly dumped and allowed 
to decompose causing environmental challenges. Hence, various strategies have been proposed for the valorisation of CP into valuable products.

\section{Cassava Peels Valorisation}

This comprises all the processes utilised to convert solid CP waste into energy, fuels, materials, chemicals and other value-added products. The idea of waste valorisation revolves around the conversion of natural products or their residues into unexploited polymeric materials that could be utilised for various applications. For instance, $\mathrm{CP}$ could be converted via anaerobic digestion into biogas. This process is a complex process that occurs with the aid of microbial bacteria in the absence of oxygen. Ighalo and Adeniyi [41] proposed thermodynamic models to examine the valorisation potential of CP via pyrolysis and steam reforming. The authors found out that CP could be effectively valorised through thermochemical processes. Figure 1 depicts the various pathways, processes and products in which solid wastes such as CP could be valorised into various products such as high-value chemicals for sustainable environment and pollution abatement. 


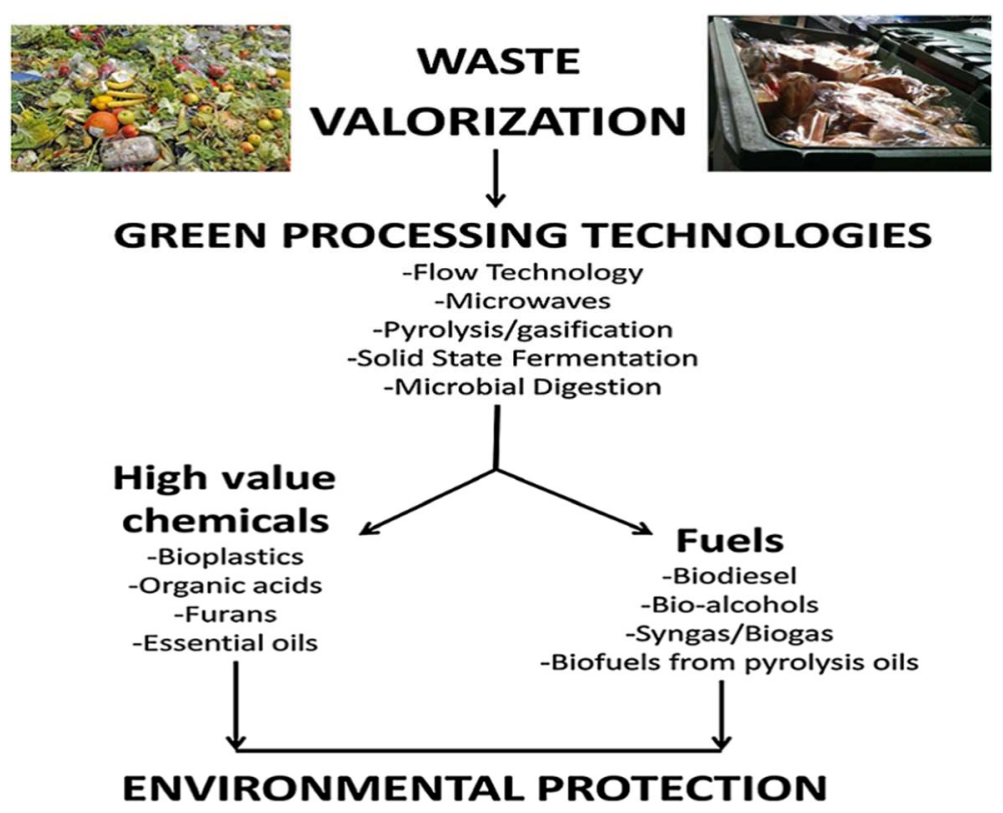

Figure 1: Green processing technologies for waste valorisation [42].

\section{Conventional Technologies for CP Valorisation}

The conventional route for the valorisation of solid wastes such as CP into biogas is through the biochemical route. The most common valorisation technologies or conversion systems for these conversion routes essentially utilize enzymes from microorganisms to strip off the energy, fuels and materials from biomass. Examples of these eco-friendly approaches are:

- Anaerobic digestion,

- $\quad$ Fermentation technology.

\subsection{Anaerobic digestion (AD)}

Anaerobic digestion (AD) is the biological disintegration of soluble complex organic matter by an intricate microbial ecosystem $[43,44]$. The process occurs through a series of metabolic routes involving various synergistic microbial environments, which lead to the production of methane $\left(\mathrm{CH}_{4}\right)$ and carbon dioxide $\left(\mathrm{CO}_{2}\right)$. However, 
Ekop et al. [45] define AD as the microbial decay or decomposition of organic matter (biomass) in the absence of oxygen. The process of AD is typically carried out in a welldesigned reactor termed anaerobic bioreactors or digesters, as depicted in Figure 2. Bioreactors are especially instruments or devices developed to ensure the production of $\mathrm{CH}_{4}$-rich biogas from solid wastes such as $\mathrm{CP}$. An anaerobic bioreactor plant is made up of digester, feedstock, digestate reservoir, and biogas holder [46].

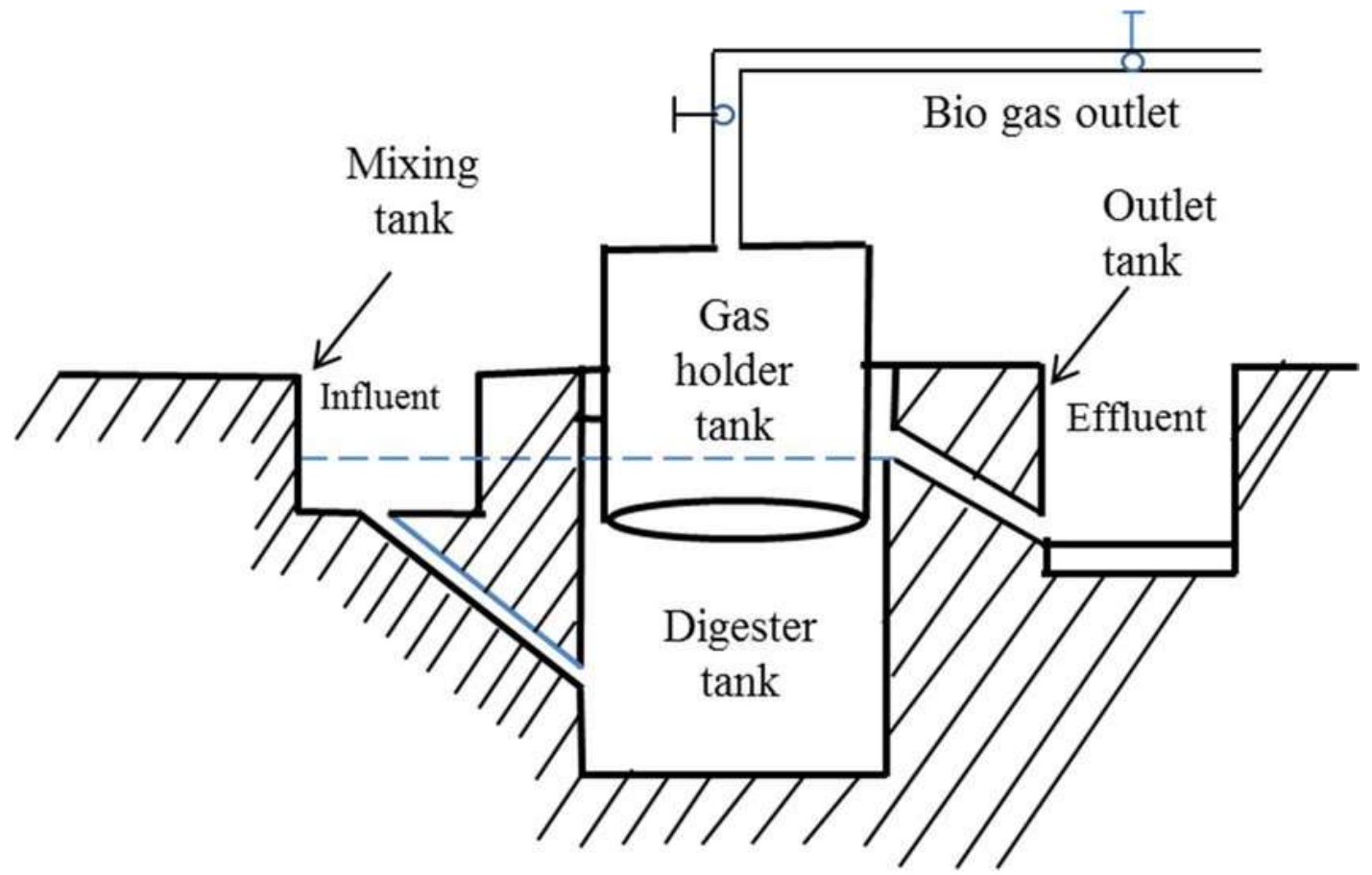

Figure 2: Schematic diagram of Biogas digester [46].

Bioreactors or digesters are typically designed with steel, gas or stainless-steel cylinder tanks with a capacity between 1 litre to over 50000 litres equipped with an agitator and integral heating or cooling system. Usually, bioreactors are more often designed and manufactured based on the growth prerequisite of the organisms (in this case, methanogens) involved. The purpose is to guarantee the successful conversion of biomass into the required by-products, which in this case is the biogas (methane and carbon dioxide). In principle, the molecule of the feedstock in the bioreactor is acted upon by an enzyme, which then diffuses through a biofilm before transforming into 
$\mathrm{CH}_{4}$ and volatile fatty acids, which subsequently diffuses out into the bulk liquid. The products and process of AD are significantly influenced by factors such as temperature, hydrogen-ion $(\mathrm{pH})$ concentration, feedstock composition and nutrients. Likewise, the ratio of carbon/nitrogen $(\mathrm{C} / \mathrm{N})$ is also a critical parameter to produce biogas during $\mathrm{AD}$. Furthermore, Tambone et al. [47] reported that anaerobic processes also partially eradicate the harmful organic content found in the waste, thereby making it less toxic and harmful when subsequently discharged into the environment or utilized as biofertilizer. The valorisation of $\mathrm{CP}$ through the process of AD has been examined in the literature. In this $\mathrm{AD}$ pathway, biogas is produced from $\mathrm{CP}$ via microorganisms. $\mathrm{AD}$ engross bacterial fermentation of organic solid waste in the absence of oxygen. During the process, CP undergoes four (4) stages in the presence of different microorganisms before biogas is obtained. The phases involved in the process include Hydrolysis, Acidogenesis, Acetogenesis, and Methanogenesis.

\section{Hydrolysis phase}

The complex insoluble organic compounds (or polymers) in $\mathrm{CP}$ such as protein, cellulose, and hemicelluloses are broken down into simpler ones (soluble monomers). This process occurs due to the secretion of hydrolytic enzymes produced from the extracellular enzymes and cofactors [48]. Typically, these enhance the degradation of polymers in $\mathrm{CP}$ into various monomers, which is enhanced by higher temperatures.

\section{Acidognesis phase}

The simpler compounds from the hydrolysis phase are further degraded into shortchain organic acids, alcohols, aldehydes, carbon dioxide, and hydrogen with the aid of acidifying bacteria. This stage is considered the fastest step in the AD process [49]. However, if $\mathrm{CP}$ has a low shock absorber capacity and the organic loading rate is high, 
the build-up of unstable fatty acids can give rise to a drop in $\mathrm{pH}$, which subsequently restrains the methanogens that produce methane in the final step.

\section{Acetogenesis phase}

In this phase, the acetate bacteria can enzymatically degrade the by-products from the acidognesis phase into acetates and $\mathrm{H}_{2}$, which may be used by methanogenic bacteria in the final stage [50]. Likewise, the acetogenic bacteria in this stage can survive under low H concentrations. Hence, high yields of hydrogen from the acidogenesis step can hinder such bacteria [51].

\section{Methanogenesis phase}

This stage of the AD process results in the production of $\mathrm{CH}_{4}$ and $\mathrm{CO}_{2}$, which make up the most significant proportion of the biogas product. It is termed the fourth and final stage of the process. Typically, this stage involves the microbial conversion of $\mathrm{H}_{2}$ and acetic acid into the biogas product [52]. Figure 3 presents the entire process for the valorisation of $\mathrm{CP}$ through $\mathrm{AD}$. Note however that it is essential that the organisms involved in each phase of the anaerobic oxidation reactions team up with the next.

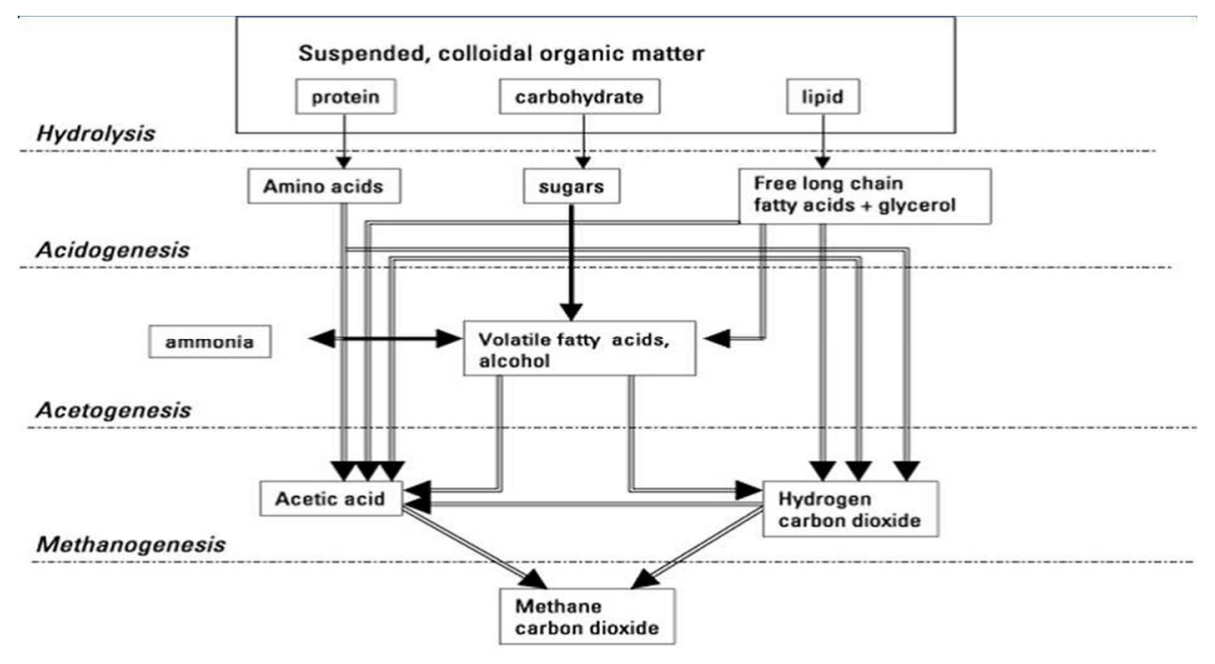

Figure 3: Schematic diagram of AD [53]. 
The three (3) biochemical reactions through which the process of methanogens functions is given as:

$$
\begin{gathered}
4 \mathrm{CH}_{3} \mathrm{COOH} \rightarrow 4 \mathrm{CO}_{2}+4 \mathrm{CH}_{4} \\
\mathrm{CO}_{2}+4 \mathrm{H}_{2} \rightarrow \mathrm{CH}_{4}+2 \mathrm{H}_{2} \mathrm{O} \\
4 \mathrm{CH}_{3} \mathrm{OH}+6 \mathrm{H}_{2} \rightarrow 3 \mathrm{CH}_{4}+2 \mathrm{H}_{2} \mathrm{O}
\end{gathered}
$$

\subsection{Fermentation}

Fermentation is a biochemical conversion technological process instigated by microbes under anaerobic surroundings. Under such processes, cellulose, sugar and starch found in biomass are transformed into ethanol and carbon dioxide as metabolic waste products [54]. The fermentation process involves the removal of contaminants that accompany the feedstock $(\mathrm{CP})$ at the source before the digestion process. In addition, the feedstock is resized to enhance the surface areas for easy access by bacteria for the hydrolyzation process. Before the fermentation of $\mathrm{CP}$, organic compounds (i.e. starch, cellulose and hemicellulose) found in the peels are pre-treated. In other words, the $\mathrm{CP}$ experiences the principle of co-metabolism where saccharolytic microorganism breaks down the complex compound. For instance, starches are first and foremost hydrolysed into fermentable sugars by enzymes from moulds before the fermentation process. Cellulosic biomass either undergoes acidic hydrolysis, enzymatic hydrolysis or gasification pre-treatment before fermentation. Gasification pre-treatment before fermentation of cellulose produces synthesis gas (i.e. $\mathrm{CO}, \mathrm{CO}_{2}$, and $\mathrm{H}_{2}$ ). Figure 4 shows the pathway for the fermentation and digestion of biomass feedstocks for the microbial production of biogas [55]. However, the use of fermentation technology to obtain energy from biomass has limits. For example, bioethanol generated from highly polluting wastes cannot be used directly in fields as biofertilizers. Likewise, bioethanol in the engine as fuels affects electric fuel pumps through internal wearing and 
unwanted flash generation. Lastly, the ethanol is hygroscopic which causes corrosion in engines [56].

Biogas production through the processes of anaerobic digestion and fermentation of biomass of any kind has come a long way. However, these processes are prone to numerous challenges. For example, the study by Fagbohungbe et al. [57] observed that one of the significant challenges of $\mathrm{AD}$ is substrate-induced inhibition. The phenomenon is known to hamper the constant operation of the process of AD by slowing down the microbial degradation of the organic waste and methane formation. As a result, the overall energy output and process efficiency are reduced considerably. In addition, the process results in the production of secondary waste or digested byproduct sludge, which requires additional costs, energy and processing for disposal, management or valorisation. In recent times, production biogas has taken new novel turns since the AD method was first to embrace technologies that are environmentally friendly and optimize biogas production.

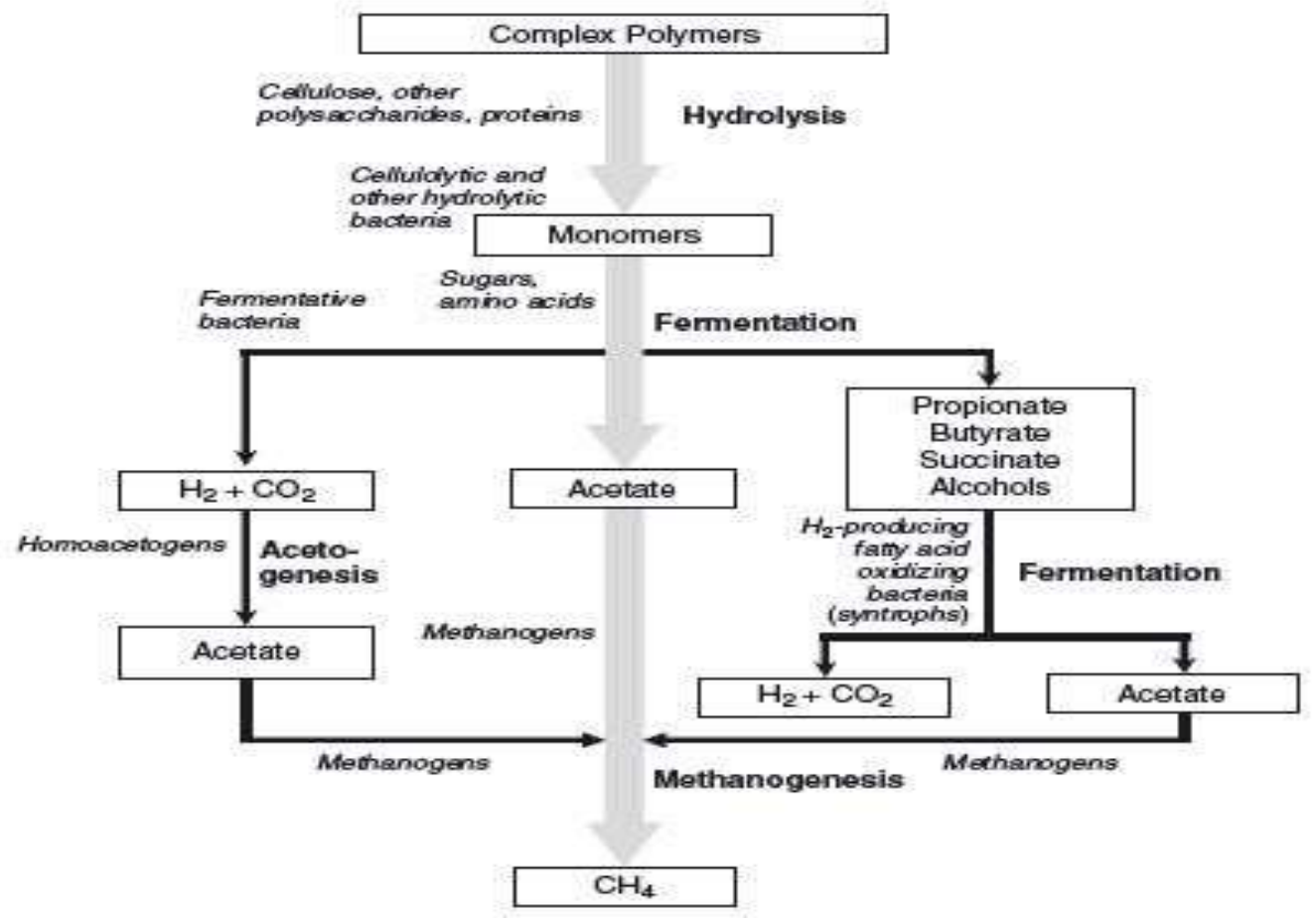

Figure 4: Schematic of anaerobic decomposition and fermentation processes [55]. 


\section{Innovative Technologies for Valorisation of CP}

Over the years, numerous innovative technologies have been proposed to valorise $\mathrm{CP}$. In general, some of the novel technologies for valorisation of $\mathrm{CP}$ into biogas are diverse but can roughly be categorised into three (3) groups, including;

- Thermal conversion,

- Thermochemical conversion,

- Plasma technologies.

\subsection{Thermal Conversion}

The process involves the conversion of thermally degradable materials such as biomass through the application of heat at low to high temperatures. During the thermal processing of biomass, the intrinsic chemical energy is harvested through direct burning. As a result, the feedstock's chemical energy is converted into heat, steam, and electricity. Typically, thermal conversion equipment such as boilers is used to convert biomass such as $\mathrm{CP}$ into heat energy which is subsequently utilised to produce steam in the industry. The pressure of the steam generated is then channelled to a spin turbine attached to a DC electrical generator that generates electrical current [58]. However, the prospects of directly utilising or combusting any biomass feedstock for energy generation largely depends on its physicochemical and calorific fuel properties [59]. Nevertheless, the open combustion of waste emits compounds like acid gases, furans, and dioxins that are harmful and at the same time, cause air pollution. As such direct burning is discouraged [60]. Kemausuor et al. [61] investigated the techno-economic and socio-economic prospects of utilising $\mathrm{CP}$ as feedstock for biogas production. The findings showed that 225 tonnes of $\mathrm{CP}$ can generate 75 million litres of gas with a methane content of $60 \mathrm{vol} . \%$. Furthermore, the analyses showed that $\mathrm{CP}$ is a potentially suitable feedstock for establishing biogas plants with capacities ranging from $300 \mathrm{~m}^{3}-$ 
$500 \mathrm{~m}^{3}$ and replace 300 tonnes of fuel wood utilised in the regions under study and prevent. Lastly, the valorisation of $\mathrm{CP}$ as fuel for biogas production dramatically reduces the emission of toxic and greenhouse gases generated annually from the open burning (Figure 5) of CP in the country.

Another important thermal technology for the valorisation of $\mathrm{CP}$ is waste incineration. In principle, the process involves the burning of waste in the presence of oxygen (oxidation) under emission control in an incinerator. The heat energy generated from the process simultaneously converts waste into various products whilst destroying pathogens present in the waste. Hence, CP could be incinerated in an incinerator. Nonetheless, $\mathrm{CP}$ could be directly transformed into $\mathrm{CO}_{2}$ and water vapour or indirectly to char, $\mathrm{H}_{2}$, and $\mathrm{CO}$ during this incineration process. Note, however, that the determining factor is the concentration of oxygen supplied. High moisture affects both incineration and combustion. Many researchers have employed technological incineration methods in the valorisation of $\mathrm{CP}$ and findings have shown tremendous efficiency [62].

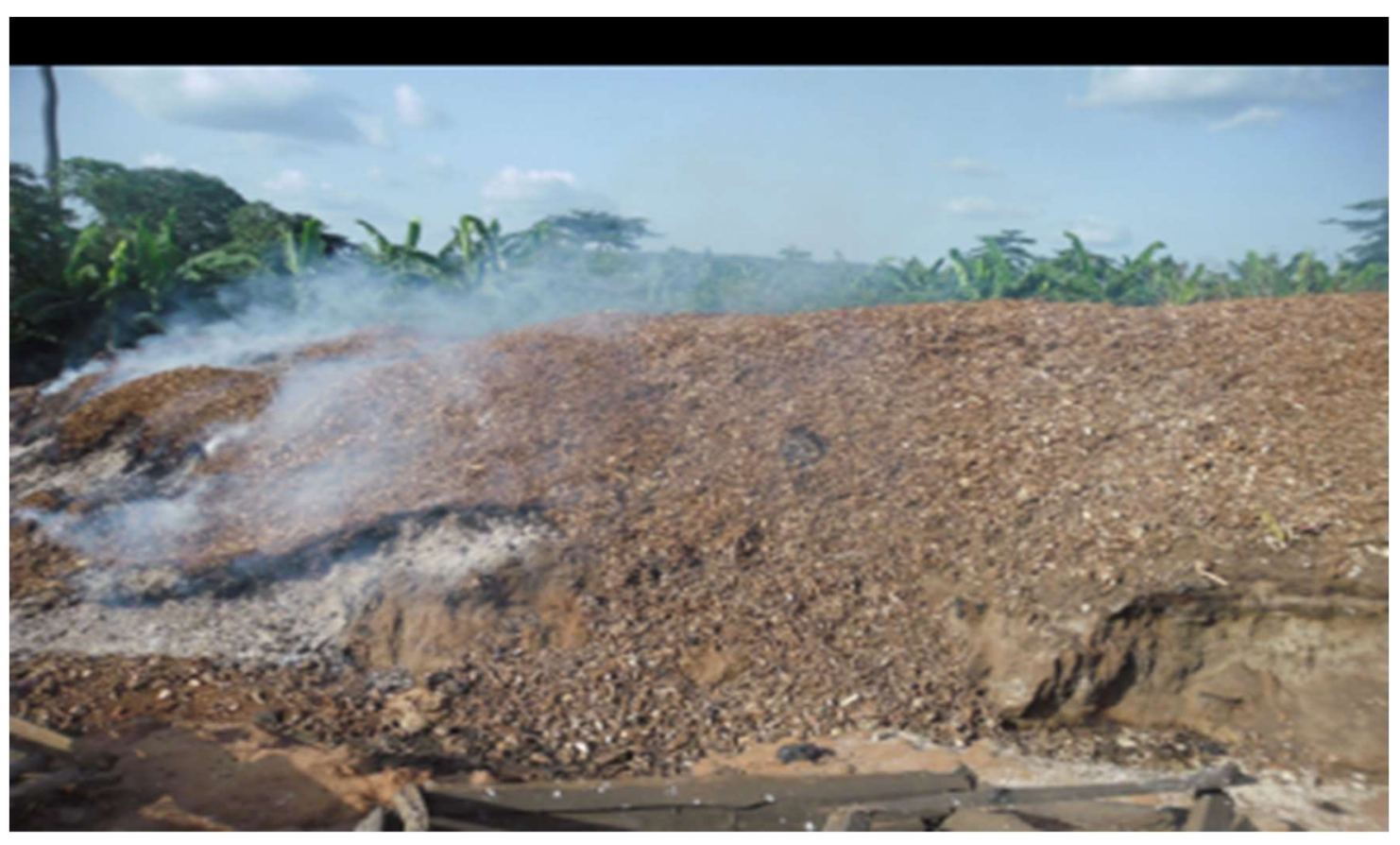

Figure 5: Open combustion of CP heap [61]. 


\subsection{Thermochemical conversion technologies}

These technologies utilize a chain of chemical reactions that occur at diverse temperatures. The processes are known to proceed in the partial presence of oxygen (gasification) or in a total absence of oxygen (pyrolysis) to form its various by-products [63]. However, the temperatures required for such processes could extend beyond or overlap the spatial and temporal stages of aeration and degassing, pyrolysis and gasification [64]. Lastly, the complete or oxidative burning of materials, which results in the conversion of organic waste into ash, is also considered a thermochemical process $[65,66]$. Figure 6 shows the overlapping technologies that make up thermochemical conversion, whereas Figure 7 shows the various thermo-conversion routes and their byproducts.

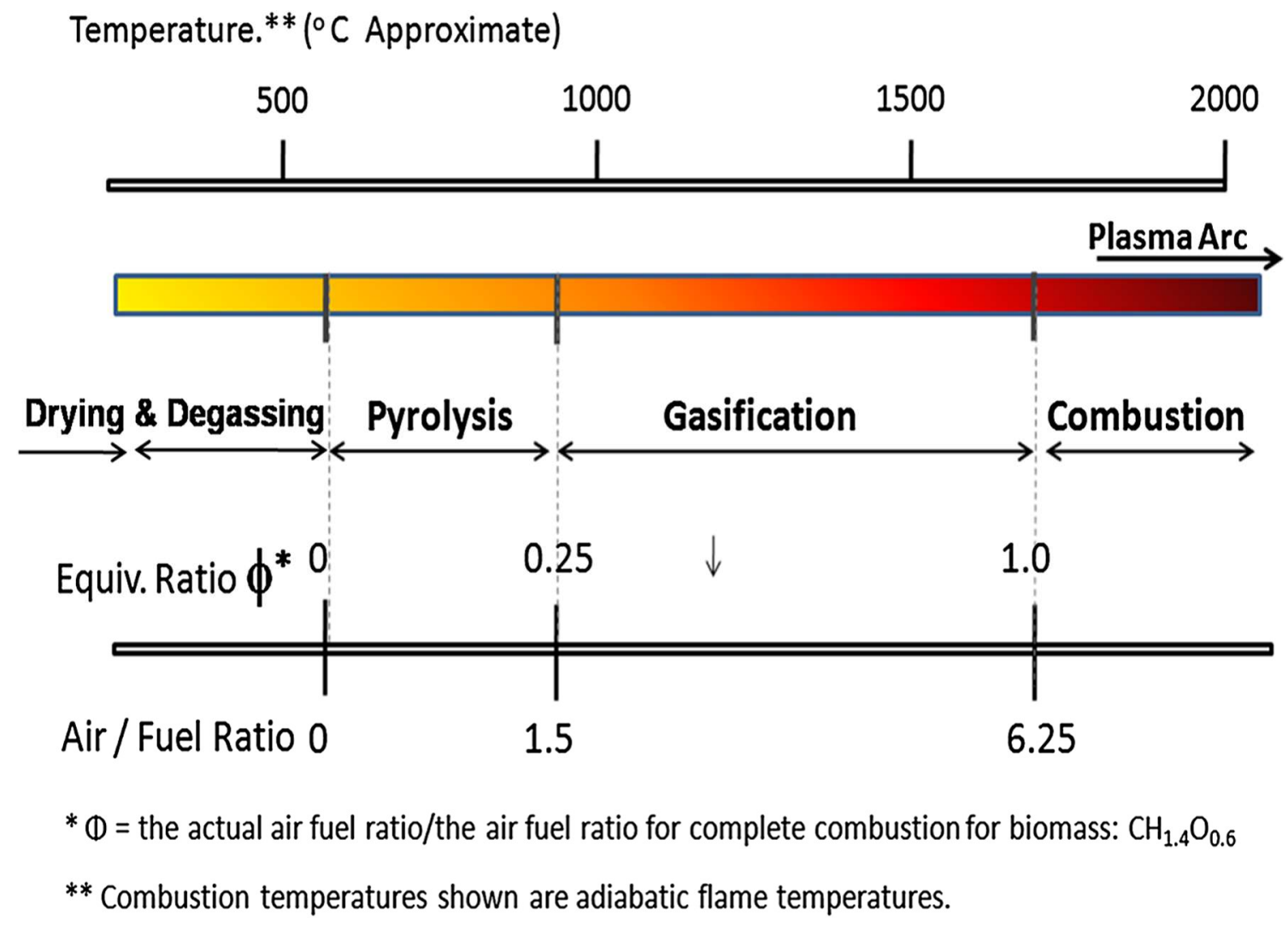

Figure 6: Temperature overlapping of thermo-chemical conversion technology. 


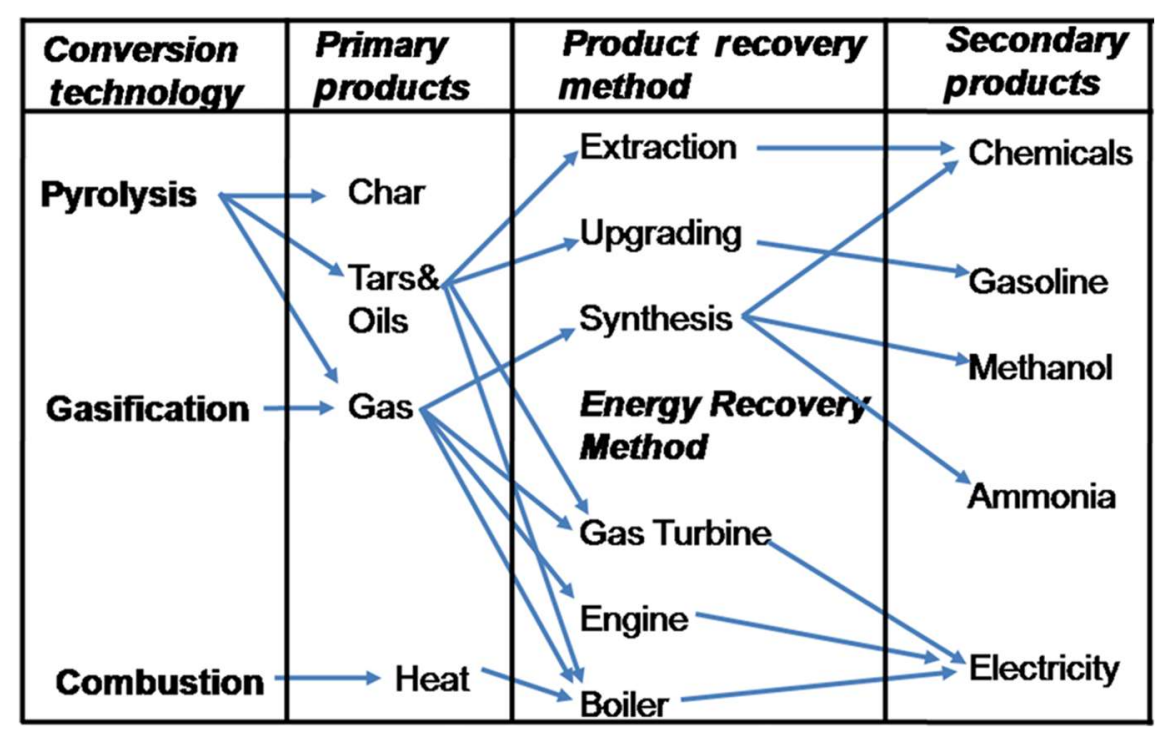

Figure 7: Thermo-conversion route and by-products [66]

Pyrolysis and gasification vary from incineration in that the former may be used for recuperating the chemical worth of the waste, whereas the latter is used to recuperate its energy worth. The chemical products produced from pyrolysis and gasification may be used as fuel or as secondary feedstock (char) for further fuel generations, which are later used to generate heat energy. However, the process of incineration does not generate fuels $[62,67,68]$.

\subsubsection{Pyrolysis}

Pyrolysis is a thermo-chemical process that involves the thermal breakdown of natural material at relatively low temperatures between $300{ }^{\circ} \mathrm{C}$ and $600{ }^{\circ} \mathrm{C}$ in the absence of oxygen $[63,65]$. The process typically results in the production of gases (non-condensable), liquid, and solid char products depending on the heating rates, gas medium, residence time, particle size and selected reactor [69]. Other products of pyrolysis include chemicals, pyrolysis oils, water, fuel gas mixtures $\left(\mathrm{H}_{2}, \mathrm{CO}_{2}, \mathrm{CH}_{4}, \mathrm{CO}\right)$, and solid (coke and char) products $[70,71]$. Due to its numerous advantages, the 
process is currently explored as a valorisation technique for the recycling or size lessening of waste streams. Ighalo and Adeniyi [41] examined the valorisation of cassava peel using pyrolysis. According to the study, when $\mathrm{CP}$ is exposed to heat, larger molecules undergo primary breakdown to yield condensable gases and solid char as by-products. Next, these condensable gasses undergo further secondary decomposition to produce the non-condensable gases which include $\mathrm{H}_{2}, \mathrm{CO}, \mathrm{CO}_{2}$, and $\mathrm{CH}_{4}$, liquid and char. These disintegration processes travel partially through gas-phase reactions and to some degree through gas-solid-phase thermal reactions. In the gas phase, the condensable vapour is cracked into tiny molecules of non-condensable stable gases which are $\mathrm{CO}$ and $\mathrm{CO}_{2}$, thus, these gases are of less concern in pyrolysis. The basic stoichiometry for pyrolysis of biomass is given as [63]:

$$
\mathrm{C}_{n} \mathrm{H}_{m} \mathrm{O}_{p} \text { (biomass) --- } \sum_{\text {liquid }} \mathrm{CxHyOz}+\sum_{\text {gas }} \mathrm{CaHbOc}+\mathrm{H}_{2} \mathrm{O}+\mathrm{C} \text { (Char) }
$$

In the process of $\mathrm{CP}$ valorisation into biogas, the $\mathrm{CP}$ are first and foremost ground to increase the surface area of the participating particles to increase the rate of heat transfer during the reaction. Secondly, these tiny ground particles of $\mathrm{CP}$ are dried to boost the competence of the reaction within the reactor. Further, the thermal breakdown of organic molecules (i.e. cellulose, hemicellulose and lignin) in CP produces pyrolysis products and eventual and secondary curing of the by-products. The leading gases produced from pyrolysis are methane, carbon monoxide, and hydrogen and are revealed by reaction Eqn 4. Pyrolysis has great intrinsic worth in waste management. This is because it presents a flexible and striking way of changing solid wastes in our environment into a quickly stocked up and movable fuel, which is further used to produce heat, power, and chemicals [63, 72, 73]. Pyrolysis gas can be used to power gas engines and gas turbines, which are used to generate electricity [74, 75]. With regards to operational parameters, pyrolysis can be classified into fast, slow, 
and flash pyrolysis. In other publications, vacuum, microwave, hydro and catalytic pyrolysis are also reported [76, 77].

\subsubsection{Gasification}

Gasification is a thermo-chemical reaction process whereby fuel reacts with gasification agents to yield synthetic gas $[63,69]$. It is a thermal conversion process whereby syngas is produced in the temperature range $600{ }^{\circ} \mathrm{C}-1000{ }^{\circ} \mathrm{C}$ through gasifiers in the partial presence of air/oxygen from carbonaceous materials. The synthetic gases include $\mathrm{H}_{2}, \mathrm{CO}, \mathrm{CO}_{2}, \mathrm{~N}_{2}$ and other hydrocarbons such as $\mathrm{C}_{2} \mathrm{H}_{4}, \mathrm{CH}_{4}$, $\mathrm{C}_{2} \mathrm{H}_{6}$, along with small quantities of $\mathrm{NH}_{3}$, tars, and $\mathrm{H}_{2} \mathrm{~S}$ may also be found [78]. The gasification process is an endothermic reaction, and as such, external heating is needed for the process [70]. In theory, gasification occurs when water vapour (steam) and carbon dioxide reacts with char in gasifiers to yield $\mathrm{H}_{2}$ and $\mathrm{CO}$. Further, within the temperature of the gasifier, both the products and reactants balanced speedily through equilibrium reaction. Synthetic gases are used as fuel for electricity production [79]. However, a combination of these gases can be used as gasification agents. Typically, the techniques used during gasification are grouped based on oxidizing medium. For instance, steam and plasma melting gasification, which is are novel gasification technologies [80]. Zhang et al. [78] reported that a gasifier is a crucial device that affects the entire process of gasification. It is classified into fixed bed, fluidized, and entrained flow gasifiers. The gasification of $\mathrm{CP}$ is a thermal conversation process that involves its thermal decomposition into principally synthetic gases. The resulting syngas is subsequently utilised for power generation, lighting, and heating [71]. Hence, the process is considered a proficient and cost-efficient system for the valorisation of solid wastes such as CP. 


\subsubsection{Plasma technology}

Plasma technology is a high-temperature thermal process that involves the change in the state of matter. For example, matter can be converted from solid-state to liquid to gases state) when heat is applied, which is the fundamental working principle of the plasma process. According to Nandkumar [81] in plasma technology, when extra heat is applied to a gaseous state. It thus further ionized into a fourth state called energy-rich plasma state. Nevertheless, the source of high thermal energy for plasma state could either come from electric current or thermal or electromagnetic radiation. Therefore, the entire process is expensive. Nonetheless, one of the merits of this technology is it tolerates low energy biomass that is not fit for other technologies such as gasification Note, however, that the high heat energy needed in plasma technology aid in the complete disintegration of organic compounds into their components and eventually yielding high-energy synthesis gas [70].

\section{Conclusion}

The paper presented an overview of the current routes and future technologies for the valorisation of CP. The large-scale generation of CP wastes annually creates significant disposal and management problems, which could pose risks to human health, safety and the environment annually. Therefore, it has become imperative to identify and examine sustainable measures to address the disposal and management challenges posed by the growing problem of $\mathrm{CP}$ waste accumulation in the environment. Therefore, this paper reviewed the potential valorisation technologies used for $\mathrm{CP}$ wastes in the literature. The review of the literature showed that biochemical routes, including anaerobic digestion and fermentation, are the most widely current routes for the valorisation of $\mathrm{CP}$. The $\mathrm{AD}$ process results in the production of biogas comprising methane and carbon dioxide, whereas fermentation 
results in the production of bioethanol. However, the conventional techniques are prone to numerous challenges such as substrate-induced inhibition, which hamper the process of $\mathrm{AD}$ by reducing microbial degradation, methane formation, energy output and process efficiency. Furthermore, the $\mathrm{AD}$ and fermentation processes generate secondary waste or digested by-product sludge, which requires additional costs, energy and processing for disposal, management or valorisation. Therefore, innovative approaches such as thermal, thermochemical, and plasma technologies have been proposed to produce various products such as syngas, biofuels, bioenergy, biochemicals, and fertilizers, among others. However, the process of the fermentation process is plagued by the inability to reuse fermentation waste residues in fields as biofertilizers, whereas bioethanol causes corrosion in engines. Overall, the review of the literature revealed that the biochemical (particularly AD), thermal, thermochemical and plasma technologies do not only valorise waste into various products but also generate net energy.

\section{References}

[1] Höök, M. and X. Tang. (2013). Depletion of fossil fuels and anthropogenic climate change-A review. Energy policy, 52: 797-809.

[2] Covert, T., M. Greenstone, and C.R. Knittel. (2016). Will we ever stop using fossil fuels? Journal of Economic Perspectives, 30(1): 117-38.

[3] Wong, S.L., B.B. Nyakuma, A.H. Nordin, C.T. Lee, N. Ngadi, K.Y. Wong, and O. Oladokun. (2020). Uncovering the dynamics in global carbon dioxide utilization research: a bibliometric analysis (1995-2019). Environmental Science and Pollution Research.

[4] Johari, A., B.B. Nyakuma, S.H.M. Nor, R. Mat, H. Hashim, A. Ahmad, Z.Y. Zakaria, and T.A.T. Abdullah. (2015). The challenges and prospects of palm oil based biodiesel in Malaysia. Energy, 81: 255-261. 
[5] Ivase, T.J.-P., B.B. Nyakuma, O. Oladokun, P.T. Abu, and M.N. Hassan. (2020). Review of the principal mechanisms, prospects, and challenges of bioelectrochemical systems. Environmental Progress \& Sustainable Energy, 39(1): 13298.

[6] Oladokun, O., B.B. Nyakuma, and A. Ahmad, Fundamental Theories and Kinetic Models for the Pyrolysis of Lignocellulosic Biomass Wastes, in Handbook of Research on Resource Management for Pollution and Waste Treatment. 2020, IGI Global. p. 123151.

[7] Nyakuma, B.B., S. Wong, G.R. Mong, L.N. Utume, O. Oladokun, K.Y. Wong, T.J.P. Ivase, and T.A.T. Abdullah. (2021). Bibliometric analysis of the research landscape on rice husks gasification (1995-2019). Environmental Science and Pollution Research: 1-24.

[8] Kumar, A., Global warming, climate change and greenhouse gas mitigation, in Biofuels: Greenhouse Gas Mitigation and Global Warming. 2018, Springer. p. 1-16.

[9] Wong, S.L., B.B. Nyakuma, K.Y. Wong, C.T. Lee, T.H. Lee, and C.H. Lee. (2020). Microplastics and nanoplastics in global food webs: A bibliometric analysis (2009-2019). Marine Pollution Bulletin, 158: 111432.

[10] Yüksel, İ. (2009). The Role of renewables in meeting Turkey's energy demand. Energy Sources, Part A: Recovery, Utilization, and Environmental Effects, 31(20): 1915-1925.

[11] Kumar, S. (2016). Assessment of renewables for energy security and carbon mitigation in Southeast Asia: The case of Indonesia and Thailand. Applied Energy, 163: 63-70.

[12] Akinbami, J.-F., M. Ilori, T. Oyebisi, I. Akinwumi, and O. Adeoti. (2001). Biogas energy use in Nigeria: current status, future prospects and policy implications. Renewable and Sustainable Energy Reviews, 5(1): 97-112. 
[13] Kulkarni, M.B. and P. Ghanegaonkar. (2019). Methane enrichment of biogas produced from floral waste: A potential energy source for rural India. Energy Sources, Part A: Recovery, Utilization, and Environmental Effects, 41(22): 27572768.

[14] Katuwal, H. and A.K. Bohara. (2009). Biogas: A promising renewable technology and its impact on rural households in Nepal. Renewable and sustainable energy reviews, 13(9): 2668-2674.

[15] Chen, Y., G. Yang, S. Sweeney, and Y. Feng. (2010). Household biogas use in rural China: A study of opportunities and constraints. Renewable and sustainable energy reviews, 14(1): 545-549.

[16] Van Buren, A. (1979). Chinese biogas manual: popularising technology in the countryside.

[17] Wantanee, A. (2004). Laboratory scale experiments for biogas production from cassava tubers.

[18] Mel, M., S.I. Ihsan, and R.H. Setyobudi. (2015). Process improvement of biogas production from anaerobic co-digestion of cow dung and corn husk. Procedia Chemistry, 14: 91-100.

[19] FAO, I. The global cassava development strategy and implementation plan, V. 1. in Proceedings of the validation forum on the global cassava development strategy. 2000.

[20] Kongkiattikajorn, J. and B. Sornvoraweat. (2011). Comparative study of bioethanol production from cassava peels by monoculture and co-culture of yeast. Agriculture and Natural Resources, 45(2): 268-274.

[21] Ogunbode, E.B., B.B. Nyakuma, R.A. Jimoh, T.A. Lawal, and H.G. Nmadu. (2021). Mechanical and microstructure properties of cassava peel ash-based kenaf bio-fibrous concrete composites. Biomass Conversion and Biorefinery: https://doi.org/10.1007/s13399-021-01588-6. 
[22] Gin, W., A. Jimoh, A. Abdulkareem, and A. Giwa. (2014). Utilization of cassava peel waste as a raw material for activated carbon production: approach to environmental protection in Nigeria. International Journal of Engineering Research and Technology, 3(1): 36-42.

[23] Ogunyemi, A.K., T.A. Samuel, M.O. Ilori, and O.O. Amund. (2019). Cassava wastewater and solid waste leachate as cyanogenic substrates for the growth of Nitrile and Linamarin-utilizing bacteria.

[24] Osinowo, O.O., M.A. Agbaje, and S.O. Ariyo. (2020). Integrated geophysical investigation techniques for mapping cassava effluent leachate contamination plume, at a dumpsite in Ilero, southwestern Nigeria. Scientific African, 8: e00374.

[25] Cuzin, N., J.-L. Farinet, C. Segretain, and M. Labat. (1992). Methanogenic fermentation of cassava peel using a pilot plug flow digester. Bioresource technology, 41(3): 259-264.

[26] Adeyemo, S. and A. Adeyanju. (2008). Improving biogas yield using media materials. JEAS-Journal of Engineering \& Applied Sciences, 3(2): 207-210.

[27] Adelekan, B. and A. Bamgboye. (2009). Comparison of biogas productivity of cassava peels mixed in selected ratios with major livestock waste types. African Journal of Agricultural Research, 4(7): 571-577.

[28] Ukpai, P. and M. Nnabuchi. (2012). Comparative study of biogas production from cow dung, cow pea and cassava peeling using 45 litres biogas digester. Advances in Applied Science Research, 3(3): 1864-1869.

[29] Ofoefule, A. and E. Uzodinma. (2009). Biogas production from blends of cassava (Manihot utilissima) peels with some animal wastes.

[30] Okudoh, V. and C. Trois. (2014). The potential of cassava biomass as a feedstock for sustainable biogas production in South Africa. Journal of Energy and Power Engineering, 8(5). 
[31] Bayitse, R., G. Laryea, G. Selormey, W. Oduro, M. Aggey, B. Mensah, M. Gustavsson, and A. Bjerre. (2014). Anaerobic co-digestion of cassava peels and manure: A technological approach for biogas generation and biofertilizer production - A feature article. Journal of Applied Science \& Technology, 19.

[32] Ismadjia, S., Y.-H. Jub, C.X. Linc, A. Kurniawana, and O.L. Kia. Bio-oil from cassava peel: potential renewable energy source. in The 5th International Conference on Industrial Bioprocesses Taipei. 2012.

[33] Sunmonu, M., M. Sanusi, and H. Lawal. (2021). Effect of different processing conditions on quality of cassava. Croatian journal of food science and technology, 13(1): 69-77.

[34] Aso, S.N., P.C. Pullammanappallil, A.A. Teixeira, and B.A. Welt. (2017). Production of glucose sweetener by simple single-step hydrolysis of native cassava root starch. Transactions of the ASABE, 60(6): 2199-2207.

[35] Aro, S., J. Agbede, and V. Aletor. (2010). Energy value of cassava tubers byproducts fermented naturally and through a consortium of microorganisms. Biotechnology Development and Threat of Climate Change in Africa: The Case of Nigeria, 1: 133-139.

[36] Adesanya, O., L. Shittu, and R. Adesanya. (2008). Cassava Processing. Internet Journal of Microbiology, 5(1): 25-35.

[37] Odunfa, A., S. Olabiwoninu, and S. Odunfa. (2012). Enhancing the production of reducing sugars from cassava peels by pretreatment methods. International J. Sci. Technol, 2(9): 650-657.

[38] Okafor, N. An integrated bio-system for the disposal of cassava wastes, integrated biosystems in zero emissions applications. in Proceedings of the internet Conference on integrated Bio-Systems http://www. ias. unu. edu/proceedings/icibs. 1998.

[39] Hillocks, R.J., J. Thresh, and A. Bellotti. (2002). Cassava: biology, production and utilization. 
[40] Spencer, D.S. and S. Leone, Cassava cultivation in sub-Saharan Africa Chuma Ezedinma, UNIDO, Nigeria, in Achieving sustainable cultivation of cassava Volume 1. 2017, Burleigh Dodds Science Publishing. p. 141-157.

[41] Ighalo, J.O. and A.G. Adeniyi. (2021). Modelling the Valorisation of Cassava Peel (Manihot esculenta) Waste Via Pyrolysis and in-Line Steam Reforming. Environmental Processes, 8(1): 267-285.

[42] Arancon, R.A.D., C.S.K. Lin, K.M. Chan, T.H. Kwan, and R. Luque. (2013). Advances on waste valorization: new horizons for a more sustainable society. Energy Science \& Engineering, 1(2): 53-71.

[43] Gumisiriza, R., A.M. Mshandete, M.S.T. Rubindamayugi, F. Kansiime, and A.K. Kivaisi. (2009). Enhancement of anaerobic digestion of Nile perch fish processing wastewater. African Journal of Biotechnology, 8(2).

[44] Forster-Carneiro, T., M. Pérez, and L. Romero. (2008). Anaerobic digestion of municipal solid wastes: Dry thermophilic performance. Bioresource technology, 99(17): 8180-8184.

[45] Ekop, I., K. Simonyan, and E. Evwierhoma. (2019). Utilization of cassava wastes for value added products: An overview. International Journal of Scientific Engineering and Science, 3(1): 31-39.

[46] Rahman, M.M., M.F. Hasan, A. Saat, and M.A. Wahid. (2017). Economics of biogas plants and solar home systems: For household energy applications. Journal of Advanced Research in Fluid Mechanics and Thermal Sciences, 33(1): $14-26$.

[47] Tambone, F., B. Scaglia, G. D’Imporzano, A. Schievano, V. Orzi, S. Salati, and F. Adani. (2010). Assessing amendment and fertilizing properties of digestates from anaerobic digestion through a comparative study with digested sludge and compost. Chemosphere, 81(5): 577-583. 
[48] Shah, F.A., Q. Mahmood, M.M. Shah, A. Pervez, and S.A. Asad. (2014). Microbial ecology of anaerobic digesters: the key players of anaerobiosis. The Scientific World Journal, 2014.

[49] Vavilin, V., S. Rytov, and L.Y. Lokshina. (1996). A description of hydrolysis kinetics in anaerobic degradation of particulate organic matter. Bioresource Technology, 56(2-3): 229-237.

[50] Schink, B. (1997). Energetics of syntrophic cooperation in methanogenic degradation. Microbiology and molecular biology reviews, 61(2): 262-280.

[51] Deublein, D. and A. Steinhauser. (2011). Biogas from waste and renewable resources: an introduction.

[52] Verma, S. (2002). Anaerobic digestion of biodegradable organics in municipal solid wastes. Columbia University, 7(3): 98-104.

[53] Lettinga, G., L. Hulshof Pol, and G. Zeeman. (1996). Biological wastewater treatment. Part I: Anaerobic wastewater treatment. Lecture Notes. Wageningen Agricultural University, ed.

[54] Sugathapala, A. and S. Chandak. (2013). Technologies for converting waste agricultural biomass to energy. UNEP-United Nations Environment Programme. Division of Technology, Industry and Economics International Environmental Technology Centre Osaka.

[55] Madigan, M.T., J.M. Martinko, and J. Parker. (1997). Brock biology of microorganisms (Vol. 11).

[56] Hassan, M.H. and M.A. Kalam. (2013). An overview of biofuel as a renewable energy source: development and challenges. Procedia Engineering, 56: 39-53.

[57] Fagbohungbe, M.O., B.M. Herbert, L. Hurst, C.N. Ibeto, H. Li, S.Q. Usmani, and K.T. Semple. (2017). The challenges of anaerobic digestion and the role of biochar in optimizing anaerobic digestion. Waste management, 61: 236-249. 
[58] Shah, S., V. Venkatramanan, and R. Prasad. (2021). Bio-valorization of Waste: Trends and Perspectives.

[59] Tock, J.Y., C.L. Lai, K.T. Lee, K.T. Tan, and S. Bhatia. (2010). Banana biomass as potential renewable energy resource: A Malaysian case study. Renewable and sustainable energy reviews, 14(2): 798-805.

[60] Scarlat, N., V. Motola, J.F. Dallemand, F. Monforti-Ferrario, and L. Mofor. (2015). Evaluation of energy potential of municipal solid waste from African urban areas. Renewable and Sustainable Energy Reviews, 50: 1269-1286.

[61] Kemausuor, F., A. Addo, and L. Darkwah. (2015). Technical and socioeconomic potential of biogas from cassava waste in Ghana. Biotechnology research international, 2015.

[62] Wong, S., A.X.Y. Mah, A.H. Nordin, B.B. Nyakuma, N. Ngadi, R. Mat, N.A.S. Amin, W.S. Ho, and T.H. Lee. (2020). Emerging trends in municipal solid waste incineration ashes research: a bibliometric analysis from 1994 to 2018. Environmental Science and Pollution Research, 27(8): 7757-7784.

[63] Basu, P. (2010). Biomass Gasification and Pyrolysis: Practical Design and Theory.

[64] Baskar, C., S. Baskar, and R.S. Dhillon. (2012). Biomass conversion: The interface of biotechnology, chemistry and materials science.

[65] Sims, R.E.H. (2002). The Brilliance of Bioenergy: in Business and in Practice.

[66] Bridgwater, A. (1994). Catalysis in thermal biomass conversion. Applied Catalysis A: General, 116(1-2): 5-47.

[67] Jereme, I.A., C. Siwar, and A.H. Bhuiyan. (2013). Incineration and its implications: The need for a sustainable waste management system in Malaysia. International Journal of Environmental Sciences, 4(3): 367-378.

[68] Xing, Y., H. Zhang, W. Su, Q. Wang, H. Yu, J. Wang, R. Li, C. Cai, and Z. Ma. (2019). The bibliometric analysis and review of dioxin in waste incineration and steel sintering. Environmental Science and Pollution Research. 
[69] Basu, P. (2013). Biomass gasification, pyrolysis and torrefaction: practical design and theory.

[70] Nyakuma, B.B. and T.J.-P. Ivase. (2021). Emerging trends in sustainable treatment and valorisation technologies for plastic wastes in Nigeria: A concise review. Environmental Progress \& Sustainable Energy: e13660.

[71] Awasthi, A.K., M. Shivashankar, and S. Majumder. Plastic solid waste utilization technologies: a review. in IOP Conference Series: Materials Science and Engineering. 2017. IOP Publishing.

[72] Kabir, G. and B. Hameed. (2017). Recent progress on catalytic pyrolysis of lignocellulosic biomass to high-grade bio-oil and bio-chemicals. Renewable and Sustainable Energy Reviews, 70: 945-967.

[73] Kan, T., V. Strezov, and T.J. Evans. (2016). Lignocellulosic biomass pyrolysis: A review of product properties and effects of pyrolysis parameters. Renewable and Sustainable Energy Reviews, 57: 1126-1140.

[74] Bridgwater, A., A. Toft, and J. Brammer. (2002). A techno-economic comparison of power production by biomass fast pyrolysis with gasification and combustion. Renewable and Sustainable Energy Reviews, 6(3): 181-246.

[75] Chiaramonti, D., A. Oasmaa, and Y. Solantausta. (2007). Power generation using fast pyrolysis liquids from biomass. Renewable and sustainable energy reviews, 11(6): 1056-1086.

[76] Bhaskar, T. and A. Pandey, Advances in thermochemical conversion of biomassintroduction, in Recent advances in thermo-chemical conversion of biomass. 2015, Elsevier. p. 3-30.

[77] Naik, S.N., V.V. Goud, P.K. Rout, and A.K. Dalai. (2010). Production of first and second generation biofuels: a comprehensive review. Renewable and sustainable energy reviews, 14(2): 578-597. 
[78] Zhang, Y., Y. Zhao, X. Gao, B. Li, and J. Huang. (2015). Energy and exergy analyses of syngas produced from rice husk gasification in an entrained flow reactor. Journal of Cleaner Production, 95: 273-280.

[79] Bundesamt, U. (2001). Draft of a German Report with basic information for BREF-Document. Waste Incineration".[en línea]< http://files. gamta. lt/aaa/Tipk/tipk/4_kiti\% 20GPGB/63. pdf.

[80] Arena, U., L. Zaccariello, and M.L. Mastellone. (2010). Fluidized bed gasification of waste-derived fuels. Waste Management, 30(7): 1212-1219.

[81] Nandkumar, N. (2014). Plasma - the fourth state of matter. Int J Sci Technol Res, 3(9): 49-52. 